\title{
14 Value Addition in Orchids
}

\subsection{Introduction}

Value addition is a way to increase the value of a raw product anytime between harvesting and sales of the final product. A typical value addition includes processing in some ways like cleaning, cutting, packaging, smoking, drying, freezing, extracting or preserving. Value added products give a higher return, open new markets, create brand recognition and add variety to a farm operation. Value addition does not offer any guarantee on profitability. Careful planning and management are required to promote profitability. These key factors for the success of value added enterprises are quality products, good marketing and sufficient capital.

Other factors required for value added enterprises are:

- A unique product

- An enthusiastic promoter of the product

- The right kind of labeling and packaging

- Aggressive marketing

- A full time presence on the farm

- Strong agricultural or livestock knowledge

- Ability to cater to customers

- Assistance from agencies and universities

- A strong relationship with the local community

- Safe food handling and food safety regulations

- Product liability insurance

Value addition in floriculture increases the economic value and consumer appeal of any floral commodity. In floriculture, value addition is accomplished through genetic changes, processing or diversification. The profitability of a commodity is increased when a raw material is converted into a unique product. Although it requires more time, labour and skill it can significantly increase the net cash return of a small scale floriculture enterprise. Value addition gives high premium to the grower and provides quality products for the domestic and export markets. Recently, the consumption pattern is becoming diversified and leaning towards value added products such as essences, perfumes and other by-products from flowers. There is an urgent need for value addition in floricultural products through processing, packaging and supply chain management to increase farm income and generate employment (De, 2011).

The value added products from non-conventional floricultural crops like essential oils of rose, tuberose, jasmine, marigold and plant extracts used in medicines and pharmaceutical industry are unique and export-import opportunities.

Orchids comprise the largest family of flowering plants with 25,000 to 35,000 species belonging to $600-800$ genera and covers $6.83 \%$ of the flowering plants. They

(cc)BY-NC-ND ( 2014 Lakshman Chandra De, Promila Pathak, A.N. Rao, P.K. Rajeevan

This work is licensed under the Creative Commons Attribution-NonCommercial-NoDerivs 3.0 License. 
are prized for their incredible diversity in the size, shape, colour and attractiveness of their flowers and their high keeping qualities even up to 10 weeks.

\subsection{Orchids - A Component Adapted to the Diversified Climate}

Orchids are found in nearly every environment in the world. Epiphytic orchids like Thunia, Coelogyne, Cattleya, Laelia, Dendrobium, Calanthe, Bulbophyllum, Aerides, Phalaenopsis, Aranda and Aranthera with thick leaves and succulent stems have CAM and are drought tolerant with higher water use efficiency. Rhizomatous orchids like Habenaria, Eulophia etc require a terrestrial climate.

\subsection{Orchids-organically Viable}

Each orchid genus has different requirements for potting media collected from locally available organic sources. It is very important to have the correct medium for each type of orchid, depending on whether it is terrestrial or epiphytic. Growing media commonly include fir bark, coconut husk, sphagnum moss, tree fern fibres, coco peat, saw dust and perlite, and frequently a mixture of two or three of these materials. All orchids potted in a typical bark medium need to be repotted every 18 to 24 months, depending on the needs of the individual plant.

\subsection{Landscaping with Orchids}

Orchidscaping is the use of orchids permanently planted into specially prepared beds or attached to trees, shrubs or rocks in the appropriate spot in the garden. Combined with other traditional ornamentals such as palms, ferns, flowering perennials, shrubs, trees and herbs etc. it is easy to create some of the most interesting and beautiful gardens imaginable, depending upon the cost involvement and microclimatic factors. Many orchids can be grown on rocks and logs for placing in the landscape. They are attached to either cut wooden logs, coconut logs or living trees and shrubs. Once the orchids are established they will attach to the trees and logs (Teoh, 2005). In order to create visual impact in landscaping, the orchids should be planted in a single bed of one type and one colour. If someone has only one or two plants of a type, it is advisable to growing them in pots. Almost all spider orchids (Arachnis and their inter-generic hybrids, terete and semi-terete vanda, Phaius tankervillaea, Calanthe spp, and Ladies Slippers) perform well, if they are grown on the ground in full sun with liberal watering and fertilization. Sloping or flat ground with good drainage provides the ideal location for orchid beds. 


\subsection{Colour Scheme with Orchids}

To develop an orchidscape, a gardener should aware of the flowering period of each orchid. Some gardeners enjoy seasonal bursts of colour. In this case, cymbidiums and dendrobiums which flower from winter to spring should be the first choice (Friend, 2004).

\subsubsection{Winter Flowering Orchids}

Bulbophyllum hirtum, B. putidum, Cymbidium lowianum, C. mastersii, Eria bambusifolia, Paphiopedilum farrieanum, P. insigne, P. spicearum, Pleione maculata, P. praecox.

\subsubsection{Spring Flowering Orchids}

Ascocentrum ampullaceum, Calanthe plantaginea, Coelogyne cristata, Cymbidium devonianum, C. eburneum, Paphiopedilum hirsutissimum, P. villosum, Phalaenopsis lobii, Pleione humilis.

\subsubsection{Summer Flowering orchids}

Coelogyne corymbosa, C. cristata, C. nitida, C. ochracea, Cymbidium aloifolium, Dendrobium fimbriatum, D. heterocarpum, D. nobile, P. mannii, Pleione hookeriana, Phaius flavus, P. tankervillae, Renanthera imschootiana, Rhyncostylis retusa, Spathoglotis plicata, Vanda coerulea, Vanda cristata, Vanda stangeana, Vanda tessellata.

\subsection{Orchids in Balcony Gardens}

In Balcony gardens, lithophytic orchids can be grown by attaching them in free standing rocks or to the balcony's masonry walls. Genera suitable for shady location may include Bulbophyllum, Coelogyne, Eria, Maxillaria, some Oncidiums, Sarchochilus hybrids, Phalaenopsis and Cattleya hybrids.

\subsection{Orchid Tree}

An orchid tree is a variation on mounting orchids that involves the placement of many orchids on a branch or branches to give a completely natural look (Taylor, 2009). It is used in those areas of the country where orchids are grown outdoors most of the year. Usually, the larger plants are attached to the bottom and the smallest on the upper portions for 
aesthetic reasons and to provide extra weight at the bottom to balance the weight of the structure. It is better to select those plants which require similar light, temperature and humidity conditions. Another factor that has to be considered is flowering times, to get different colours on the tree throughout the year. The chosen plants are mounted on the tree with sphagnum moss and fishing wire. Thorough misting and maintenance of humidity are essential for a month to establish the plants on the structure.

\subsection{Orchids - Genetic Materials for Breeding and Species Trade}

Several local species of Vanda, Cymbidium, Ascocentrum, Paphiopedilum, Calanthe, Dendrobium, Coelogyne, Renanthera, etc are in great demand in international market for breeding materials (Tab. 14.1) (Bose and Bhattacharjee, 1980; Kumar and Sheela, 2007).

Tab. 14.1: Orchid species suitable for breeding

\begin{tabular}{|c|c|c|c|}
\hline Arachnis cathcartii & Ascocentrum ampullaceum & Bulbophyllum leopardinum & Bulbophyllum putidum \\
\hline Calanthe chloroleuca & Calanthe herbacea & Calanthe masuca & Calanthe plantaginea \\
\hline Calanthe triplicata & Coelogyne barbata & Coelogyne corymbosa & Coelogyne cristata \\
\hline Coelogyne fuscescens & Coelogyne nitida & Coelogyne ochracea & Cymbidium devonianum \\
\hline Cymbidium eburneum & Cymbidium hookerianum & Cymbidium iridioides & Cymbidium lancifolium \\
\hline Cymbidium longifolium & Cymbidium lowianum & Cymbidium munronianun & Cymbidium tigrinum \\
\hline Cymbidium tracyanum & Cymbidium whiteae & Dendrobium bensoniae & Dendrobium candidum \\
\hline Dendrobium densiflorum & Dendrobium farmeri & Dendrobium formosum & Dendrobium gibsonii \\
\hline Dendrobium infundibulum & Dendrobium nobile & Dendrobium parishii & Dendrobium pendulum \\
\hline Dendrobium primulinum & Dendrobium wardianum & Dendrobium williamsonii & Paphiopedilum fairrieanum \\
\hline $\begin{array}{l}\text { Paphiopedilum } \\
\text { hirsutissimum }\end{array}$ & Paphiopedilum insigne & Paphiopedilum spicearum & Paphiopedilum venustum \\
\hline Paphiopedilum villosum & Papilionanthe teres & Pecteilis gigantea & Phaius flavus \\
\hline Phaius tankervillea & Phalaenopsis decumbens & Phalaenopsis lobii & Phalaenopsis mannii \\
\hline Pleione hookeriana & Pleione humilis & Pleione maculata & Pleione praecox \\
\hline Renanthera imschootiana & Spathoglottis plicata & Thunia alba & Thunia marshalliana \\
\hline Thunia venosa & Vanda coerulea & Vanda corulescens & Vanda cristata \\
\hline Vanda pumila & Vanda stangeana & Vanda tessellata & Vandopsis undulata \\
\hline
\end{tabular}




\subsection{Orchid Species and Hybrids for Cut flower}

Orchid species like Cymbidium eburneum, Cymbidioum iridioides, Paphiopedilum insigne, Paphiopedilum villosum, Paphiopedilum venustum, Paphiopedilum hirsutissimum, Paphiopedilum spicerianum, Paphiopedilum fairrieanum, Renanthera imschootiana, Vanda coerulea, vanda tessellata, Zygopetalum intermedium are used as cut flowers. Orchid hybrids of Cymbidium, Dendrobium, Vanda, Phalaenopsis, Oncidium, Cattleya, Paphiopedilum, Mokara, Aranda, Renantanda etc. with different colour and forms are used as cut flowers, floral displays and exhibits (Bhattacharjee and De, 2005; De, 2011; De, et al, 2013).

\subsection{Orchids - as Potted plants/Hanging Baskets/ Trays}

Potted orchids last for longer than cut flowers, their shelf life being three weeks to four months depending upon species and hybrids (Nagrare and Ram Pal, 2008). Tall growing monopodial orchids are best grown in large clay pots up to $30 \mathrm{~cm}$ in diameter. Terrestrial and semi-terrestrial plants like Paphiopedilum and Cymbidium perform better in deep pots.

Orchid plants, as a rule grow, to be near one another to aid in creating a microclimate higher in humidity. Basket culture is useful for those orchids like Vanda, Rhyncostylis, Arachnis with pendent flower spikes and long dangling roots. Clay pots are best suitable for terrestrial orchids. Plastic pots are used for epiphytes. Slabs or logs of tree fern are effective for cool growing orchids.

Important orchid genera used as potted plants in the international market are Phalaenopsis, Oncidium, Miltonia, Cymbidium, Paphiopedilum, Dendrobium, Cattleya, Ascocenda, Vanda, Brassia, Miltonia and Epidendrum (Lopez and Runkle, 2005).

\subsection{Orchids - as Herbal Medicine and Aromatic Products}

Tribal people of the North eastern hill region use wild orchids for a variety of folk medicine, as orchids are rich in alkaloids, flavonoids, glycosides, carbohydrates and other phytochemicals (Tab. 14.2).

Tab. 14.2: Common medicinal orchids (Rao,2004)

\begin{tabular}{|c|c|c|}
\hline Name of species & Parts used & Uses \\
\hline Acampe papillosa & Root & Rheumatism, Sciatica and uterine diseases \\
\hline Aerides odorata & fruit, leaves & $\begin{array}{l}\text { The ground fruit used for healing wounds. Juice } \\
\text { of leaves is used to heal boils in ear and nose }\end{array}$ \\
\hline Cymbidium aloifolium & whole plant & $\begin{array}{l}\text { Ground plant to cure chronic illness, weakness } \\
\text { of eyes, vertigo and paralysis }\end{array}$ \\
\hline
\end{tabular}


Tab. 14.2: Common medicinal orchids (Rao,2004)

\begin{tabular}{|c|c|c|}
\hline Name of species & Parts used & Uses \\
\hline Dendrobium nobile & Stems & $\begin{array}{l}\text { Fresh and dried stems used in preparation of } \\
\text { chinese drugs for longevity and as aphrodisiac, } \\
\text { stomachic and analgesic }\end{array}$ \\
\hline Habenaria acuminata & Roots & Roots are used as tonic \\
\hline Phaius tankervilleae & Pseudobulbs & $\begin{array}{l}\text { Pseudobulb is used to heal swellings of hands } \\
\text { and legs, poultice to soothe pain of abscess }\end{array}$ \\
\hline Pholidota imbricata & Pseudobulbs & $\begin{array}{l}\text { Pseudobulbs are mixed with mustard oil and } \\
\text { applied on joints for rheumatic pain }\end{array}$ \\
\hline Rhyncostylis retusa & Roots & $\begin{array}{l}\text { Roots are effective against rheumatism, } \\
\text { asthma, tuberculosis, cramps, epilepsy, } \\
\text { vertigo, kidney stone, menstrual disorder }\end{array}$ \\
\hline Arundina graminifolia & Stems & Bulbous stems are used to heal cracks \\
\hline Dendrobium densiflorum & Leaves & $\begin{array}{l}\text { Leaves crushed to paste with salt and applied } \\
\text { on fractured area to set bones }\end{array}$ \\
\hline Vanda corulea & Leaves & $\begin{array}{l}\text { Leaf juice is used against diarrhea, dysentery } \\
\text { and external application for skin diseases }\end{array}$ \\
\hline Vanda teres & Leaves & Leaf paste to reduce temperature in fever \\
\hline Vanda cristata & Leaves & Leaves are used as tonic and expectorant \\
\hline Dendrobium moschatum & Leaves & Leaf juice is used as ear drop \\
\hline Aerides multiflorum & Tubers & Anti-bacterial \\
\hline Anoectochilus formosanus & Tubers & Hepatitis, hypertension, cancer \\
\hline Bletilla striata & Pseudobulbs & $\begin{array}{l}\text { Anti-bacterial, anti-inflammatory, demulcent, } \\
\text { skin styptic }\end{array}$ \\
\hline Cypripedium pubescens & Roots & $\begin{array}{l}\text { Anti-spasmodic, diaphoretic, hypnotic, sedat- } \\
\text { ive, tonic }\end{array}$ \\
\hline Orchis latifolia & Roots & $\begin{array}{l}\text { Aphrodisiac, expectorant, nervine tonic, dia- } \\
\text { betes, diarrhea, dysentery }\end{array}$ \\
\hline Eulophia nuda & Tubers & Worm infestation, Scrofula \\
\hline Habenaria edgeworthii & Leaves and roots & Blood diseases \\
\hline Habenaria intermedia & Leaves and roots & Blood diseases \\
\hline Habenaria pectinata & Leaves and tubers & Arthritis \\
\hline Malaxis acuminata & Pseudo-bulb & Bleeding diathesis, burning sensation, fever \\
\hline Orchis laxiflora & Bulb & Diarrhea, bronchitis, convalescence \\
\hline Vanda spathulata & Flowers & Consumption, asthma, mania \\
\hline Vanda tessellata & Whole Plant & Fever, arthritis, rheumatism, bronchitis \\
\hline Calanthe discolor & Whole plant & Hair restoring \\
\hline Dendrobium chrysanthum & Leaves & Antipyretic, Immunoregulatory, skin diseases \\
\hline Dendrobium loddigessii & Leaves & Stomach tonic \\
\hline Habenaria repens & Tubers & Aphrodisiac \\
\hline Pholidota chinensis & Pseudobulbs & Scrofula, toothache and stomachache \\
\hline Vanilla planifolia & Sheath & Hysteria, fever, impotence, rheumatism \\
\hline Cymbidium aloifolium & Rhizomes & $\begin{array}{l}\text { Salep; used as nutrient and demulcent; as } \\
\text { emetic and purgative }\end{array}$ \\
\hline
\end{tabular}


continued

Tab. 14.2: Common medicinal orchids (Rao,2004)

\begin{tabular}{lll}
\hline Name of species & Parts used & Uses \\
\hline C. ensifolium & Rhizomes \& & Eye sores \\
& Flowers & \\
C. longifolium & Pseudobulb & As emetic and demulcent \\
C. giganteum & Leaf juice & Blood clotting \\
\hline
\end{tabular}

\subsection{Fragrant Orchids}

Fragrant orchids are delightful in outdoor living areas. Brassovola species are perfumed at night and the Australian native Dendrobiums perfume the air on warm spring mornings. Other aromatic orchids are Aerides multiflorum, Aerides odoratum, Aeranthes, Bulbophyllum odoratissimum, Cattleya maxima, Coelogyne cristata, Coelogyne ochracea, Cymbidium ensifolium, Dendrobium nobile, Epidendrum cristatum, Epidendrum floribundum, Epidendrum nocturnum, Lycaste, Oncidium spaceolatum, Phaius tankervilleae, Rhyncostylis retusa, Vanda cristata, Vanda tesselata, Zygopetalum intermedium.

\subsection{Orchids - as Source of Phytochemicals}

Many medicinal orchids are rich in alkaloids. Experimental studies have been conducted on the isolation of a number of alkaloids like anthocyanins, stilebnoids and triterpenoids from orchids. Orchinol, hircinol, cypripedin, jibantine, nidemin and loroglossin have been isolated from orchids.

Several phytochemicals isolated from orchids along with active ingredient are listed in Tab. 14.13.

Tab. 14.3: Phytochemicals from orchids

\begin{tabular}{llll}
\hline $\begin{array}{l}\text { Sl. } \\
\text { No. }\end{array}$ & Name of orchid & $\begin{array}{l}\text { Phyto-Chemical } \\
\text { class }\end{array}$ & Name of phytochemical \\
\hline 1 & $\begin{array}{l}\text { Aerides crispum } \\
2\end{array} \begin{array}{l}\text { Agrostophyllum } \\
\text { brevipes } \\
\text { Agrostophyllum } \\
\text { callosum }\end{array}$ & $\begin{array}{l}\text { Phenanthropyran } \\
\text { Triterpenoid }\end{array}$ & $\begin{array}{l}\text { Aeridin } \\
\text { Agrostophyllinol }\end{array}$ \\
$4 \begin{array}{l}\text { Agrostophyllum } \\
\text { callosum }\end{array}$ & Stiterpenoid & Isoagrostophyllol \\
& & $\begin{array}{l}\text { Orchinol, 6-methoxycoelonin, imbricatin, flaccidin, } \\
\text { oxoflaccidin, oxoflaccidin, isooxoflaccidin, } \\
\text { flaccidinin, agrostophyllin, callosin, callosinin, } \\
\text { callosumin, callosuminin, callosumidin }\end{array}$ \\
\hline
\end{tabular}


Tab. 14.3: Phytochemicals from orchids

\begin{tabular}{|c|c|c|c|}
\hline $\begin{array}{l}\text { Sl. } \\
\text { No. }\end{array}$ & Name of orchid & $\begin{array}{l}\text { Phyto-Chemical } \\
\text { class }\end{array}$ & Name of phytochemical \\
\hline 5 & $\begin{array}{l}\text { Arundina } \\
\text { graminifolia }\end{array}$ & Stilbenoids & Arundinan \\
\hline 6 & $\begin{array}{l}\text { Cypripedium } \\
\text { calceolus } \\
\text { pubescens }\end{array}$ & $\begin{array}{l}\text { 1-4 phenan- } \\
\text { threnequinone }\end{array}$ & Cypripedin \\
\hline 7 & Orchis latifolia & Glucoside & Loroglossin \\
\hline 8 & $\begin{array}{l}\text { Dendrobium } \\
\text { macraei }\end{array}$ & Alkaloid & Jebantine \\
\hline 9 & Dendrobium nobile & Bibenzyl & Gigantol \\
\hline 10 & Dendrobium nobile & Bibenzyl & Moscatilin \\
\hline 11 & Dendrobium nobile & Alkaloid & Dendrobine \\
\hline 12 & Dracula chimaera & Anthocyanins & \\
\hline 13 & Eulophia nuda & Phenanthrene & Nudol \\
\hline 14 & Vanda roxburghii & Glycoside & Melianin \\
\hline 15 & Nidema boothi & Triterpenoid & Nidemin \\
\hline 16 & $\begin{array}{l}\text { Anoectochilus } \\
\text { formosanus }\end{array}$ & Glycoside & Kinsenoside \\
\hline 17 & $\begin{array}{l}\text { Dendrobium } \\
\text { moschatum }\end{array}$ & Phenanthrene & Rotundatin and moscatin \\
\hline 18 & $\begin{array}{l}\text { Bulbophyllum } \\
\text { gymopus }\end{array}$ & Phenanthrene & Gymopsin \\
\hline
\end{tabular}

\subsection{Orchids - Used as Foods}

Leaves, tubers and pseudobulbs of different species are used for edible purposes. Vanilla, a major spice crop and source of vanillin, comes from Vanilla planifolia. Anoectochilus leaves are used as vegetables in Indonesia and Malayasia. Pseudobulbs of Cymbidium maladimum and Dendrobium speciosum, and tubers of Microtis uniflora and Caladenia carnea are eaten. The popular beverage called as 'Faham' or 'Madagascar Tea' on the islands of Mauritius and Madagascar is prepared from the orchid Jumellea fragrans. The tubers from orchid genera such as Acianthus, Dipodium, Glossodia, Lyperanthus, Prasophyllum and Thelymitra have been used as food by the inhabitants of Australia. In Africa, the tubers of Cynorchis, Eulophia, Disa, Habenaria and Satyrium are used as food or juice is extracted from them. Roots, tubers or rhizomes of Eulophia, Gastrodia, Habenaria, Orchis, Pholidota, Platanthera and Spiranthes are used as food in Asia. Tubers of Disa engleriana, D. robusta and D. zambica, Habenaria clavata, Satyrium ambylosacco, S. buchananii and S. carsonii are used as foods in Malaysia. In Bhutan, the inflorescence or the flowers and pseudobulbs of Cymbidium spp. are eaten (Bhattacharjee and Das, 2008). 


\subsection{Orchids - a Special Item for Value Addition}

Cilindra - a gift of a glass flute containing a flowering mini Cymbidium. Stylish setting - Festive packaging for special occasions like Birthday

\subsection{Orchids - for Festivals and Special Uses}

People of Assam and Arunachal Pradesh use Rhyncostylis retusa, Papilionanthe teres, Vanda roxburghii, Aerides odoratum and many Dendrobium species in their religious and cultural festivals. In Assam, the flowering spike of Rhyncostylis retusa known as 'Kopou Phul' is used by girls to adorn their hair during the spring festival. The flowers of some other orchids like Vanda roxburghii and Coelogyne nitida are also used to adorn the hair of girls of Assam and Arunachal Pradesh in local festivals. The flowers of Papilionanthe teres are offered to Lord Buddha and spirits by the Khamtis and other Tai ethnics of Assam and Arunachal Pradesh. In the Kameng district of Arunachal Pradesh, Dendrobium hookerianum, Dendrobium nobile and Dendrobium gibsonii are considered as the symbol of purity and sanctity by the local people. Monpas consider the flowers of Cymbidium grandiflorum important for holy worship. The young naga women of Manipur wore the orange flowers of Dendrobium densiflorum behind their ears. Similarly, the flowers of Vanda coerulea are used by the women of Manipur in their hair during the autumn puja festival.

In several countries, orchid species and hybrids are used as National Flowers. For example, Vanda 'Miss Joaquim' in Singapore, Peristeria elata in Panama and Lycaste skinneri var. alba in Guatemala. Orchids are depicted on the stamps of several countries like Venezuela, USA, New Zealand, Australia, Indonesia, India, Singapore, Japan, Russia, Thailand, Malaysia and many others.

\subsection{Orchids for Dry Flowers}

Orchids are highly attractive, delicate, available in a variety of colours, and can be preserved by drying for use in flower arrangement and dried flower craft. The best method for drying orchids is using silica gel for microwave drying or by freeze drying. Drying orchids is a challenging task as these flowers are considered difficult to preserve. Dried orchids are used for different purposes, such as for use in vases and baskets and sometimes in shadow boxes. Bright flowers of orchid genera like Dendrobium, Cymbidium, Paphiopedilum Cattleya, Pholidota etc. can be used for drying. 


\subsection{Orchid Flower Arrangements}

Orchids symbolize wealth, beauty and social status. Orchids flower arrangements are good table decorations and weddings. Among orchids, Cymbidium, Dendrobium and Phalaenopsis are excellent for wedding centerpieces.

An arch decorated with chic white silk combined with white orchids can be considered an admirable orchid flower arrangement. In the home, they can be displayed in three ways viz. single flower vases, plants in pots and traditional mixed flower arrangements.

\subsection{Other Uses}

In the Philippines and New Guinea, the stems of some Dendrobium species are used to make baskets and bracelets. In some tribes, the sap of Cattleya labiata var. autumnalis is used as glue for musical instruments. In Central America, the empty pseudobulbs of Schomburgkias are used to make horns. 